\title{
Local Laborers in Papua New Guinea Mining: Attracted or Compelled to Work?
}

Benedict Y Imbun

\begin{abstract}
$\mathrm{P}$ apua New Guineans and mining have become synonymous with civil conflict and turmoil. Numerous works, mainly from the anthropological perspective, have documented the conflict-ridden industry and offered explanations for the development of community antagonism (see, eg, Filer I990; Connell and Howitt I99I; Rumsey and Weiner 200I). However, the existing literature on mining is somewhat sparse when it comes to the participation of Papua New Guineans as employees in the mines.

The major aim of this paper is to discuss local employment in Papua New Guinea mines. It does so by examining some of the challenges and conflicts that Papua New Guineans have confronted since their first contact with mining in the late I 800 s as adventurers and assistants to their participation as full-fledged paid workers in the current period. A central theme of this paper is that, although they first embraced mining as an adventure, the inevitable imposition of a capitalistic mode of mining operation compelled them to render their labor for a wage. Like miners everywhere, this paper argues, many Papua New Guineans now view mining employment as "the only way" rather than as one of many ways of making a living.
\end{abstract}

\section{Labor, Conflict, and Mining in Premodern Papua New Guinea}

Papua New Guineans have had contact with the international mining industry since the late I80os. Colonial officials, planters, soldiers, and missionaries provided other major avenues of contact with westerners (West I958; Waiko I993, 34). However, early engagement of locals with independent expatriate miners took the form of casual laboring in isolated alluvial goldfields around the country. From about the late i 870 ,

The Contemporary Pacific, Volume 18, Number 2, 315-333

(C) 2006 by University of Hawai'i Press 
the locals unhesitatingly took the opportunity to work for the miners who had trickled into areas of the islands of Milne Bay, creeks of the Sepik and Laloki rivers, and later Edie Creek in the Wau and Bulolo goldfields. Historical accounts documenting the first phase of locals' engagement with mining (for gold) indicate that they acted out of adventurousness and to prove their manhood away from the confines of their villages. They mainly served as temporary bois (assistants) for their mastas (white men, in this case independent alluvial miners), as guides, carriers, as well as pick and shovel handlers (Parr 1974; Gibbney 1972; Nelson 1992, I I). Yet historical documentation is vague about the social relationships between the locals and alluvial miners.

Apparently many bois were victims of attacks occasioned by local discontent in villages where the teams set up camp. In other cases, miners were responsible for inciting trouble with locals when a few of their carriers and assistants took food from the gardens, chopped trees, took women, and behaved in other ways that villagers found intolerable. Sometimes, the traditional attitudes of suspicion toward strangers were sufficient to mount a battle against invading gold prospectors. Killings of assistants and villagers resulting from conflict with alluvial miners predominated and in some cases ran into hundreds, as many of the miners had gun power (Nelson I976, 20).

If the initial phase of Papua New Guineans' engagement with mining involved adventurism and casual work arrangements, the next phase of mining was marked by bonded labor and constant conflict. The indentured labor system of the I9oos coerced locals to work for the expatriate miners, mainly in the Wau and Bulolo goldfields. This labor system involved independent miners, with the assistance of the Australian colonial state and the chiefs or "bigmen" in the traditional social system, recruiting able laborers. A major impetus for young men to accompany labor recruiters to the minefields was the promise of money with which to purchase western goods, which, in turn, would elevate their status when they returned to the villages (see Halvaksz, this issue). Laborers were subject to criminal penalties if they "deserted" their "boss" or failed to work diligently. The relationship between miner and laborer was generally characterized by a bland paternalism (Newbury 1975; Nelson 1992). The colonial governor of the time, Hubert Murray, described the system as "really rather like slavery" (Fitzpatrick I978, I00). Unlike chattel slavery, however, the admission into employment was theoretically voluntary.

Despite policing by the administration, the system was paternalistic and overtly conflict-ridden. While legal measures were intended to protect the 
"native" from exploitation by the miner, locals unused to intensive mining work and constant supervision often deserted (Newbury 1975; Nelson I992). The many who fled the Wau and Bulolo goldfields back to their villages resented their loss of autonomy.

The period from the late I920s to the mid-I960s was characterized by large-scale, capital-intensive company mining. The registration of New Guinea Goldfields Ltd and Bulolo Gold Dredging Ltd resulted in considerable changes in the colonial mining economy. Both companies brought in significant capital and skilled manpower from Australia and Britain to develop leases around the original discoveries at Edie Creek. The former established cyanide plants to process gold from both alluvial and underground mining operations. The latter established a large-scale dredging operation along the Bulolo River, where a total of eight dredges were deployed in the I930s. This period saw a sharp change from labor-intensive to capital-intensive enterprises. A spectacular achievement was the companies' use of aircraft in Bulolo and Wau to transport bulk supplies of mining equipment around the various mine airstrips, bring in workers and goods from Australia and elsewhere, and export the gold (Sinclair I978; Gammage I998). By I939 the two companies provided 80 percent of the territory's gold production and met the bulk of the industry's royalties and gold tax (Newbury 1975, 28). But large-scale mining did not entirely supersede the alluvial independent gold miners. A significant number of single leaseholders clung to their plots, while other leaseholders were absorbed into the large operations.

The many locals who formed the workforce were subjected to racial discrimination and labor conflicts (Newbury I975). Historical analysts agree that in the eight years preceding the Japanese invasion of January I 942 an average of 8,000 to I0,000 indentured local laborers and 500 to I,, $0 \circ$ Europeans were working in the Wau and Bulolo goldfields. As Nelson mentions (1992), this entailed a tenfold increase over the numbers normally deployed in alluvial prospecting and mining in the entire colony during the earlier period, which ended in the gold rush of 1926. The achievement of this period in the history of local labor was the transformation of unskilled laborers- "pick and shovel boys"-into semiskilled workers as locals were employed to fire steam boilers, work winding gear, and drive lorries in Wau and Bulolo.

Promotion up the occupational ladder for indentured laborers generated racial and labor disputes among the overwhelmingly skilled European workers. Of the four strikes that were recorded in this period, three of the principal trade disputes concerned mining companies. The issues ranged 
from an increase in wage rates to increased recruitment of indentured locals by the two companies, matters of concern to the expatriate mine workers' union. Work conditions for locals were not an issue until the old system of indenture was abolished in 1948-1950 (Newbury 1975, 28).

Because local workers had no organization to bargain collectively for them on issues affecting their welfare, they continued to resort to individualized protests. There are two plausible reasons why no early attempt was made to incorporate them into the mainstream of labor relations. One was a widespread paranoia that the "Rabaul effect" might extend beyond the mining industry to other economic sectors. Colonial administrators and planters shared this concern after the Rabaul strike of 1929 by native domestic servants. It was the first strike by a group of local workers and the speed and skill used by this group to carry out the action surprised Europeans. The white community's long-held perception of natives as "savages" was challenged and administrators continued to be anxious about the possibility of industrial strikes if legal rights to form industrial organizations were extended to natives (Gammage 1975). The second reason obstructing an early move toward industrial relations for local workers was the overriding concern of the colonial administration to isolate New Guinea from "the 'disruptive' effects of social and economic change implicit in labor mobility and wage bargaining" (Newbury I975, 38).

In short, according to the literature emanating from a number of disciplinary traditions, Papua New Guinea's mining history has gone through various stages since foreigners, with the assistance of locals, began mining. From I 878 to the I 920 s the locals had to labor while relying on the mercy of their "masters." This relationship was replaced from the late I920s to the early I960s by the indentured system, which prescribed the obligation of the local assistants and the responsibilities of individual white miners and mining companies. But it was with the establishment of the Bougainville mine in the late I960s that formal employment relationships developed. The r960s and the r970s were the beginning of the "modern" period for Papua New Guinea industrial relations as the country embraced the Australian system of collective bargaining and arbitration.

\section{Modern Large-scale Mining, Labor, And WORKER ORgANIZATIONS}

Papua New Guinean workers were exposed to the third and final phase of mining in the early I970s and I980s with the development and opera- 
tion of the giant Bougainville and Ok Tedi mines. This period, often referred to as the "modern period" of mining, saw a huge local workforce working side by side with mainly Australian and other expatriate workers (Filer 1998). Both mines superseded the Wau-Bulolo complex and introduced new technology, novel forms of work, and new complexities of managerial control to PNG mines. In general terms this is the period that effectively ended paternalistic work arrangements and replaced them with the formal establishment of industrial relations machinery (Imbun I999a).

Although local workers enthusiastically embraced mining work, this time with better training and skills in a modern Papua New Guinea, labor issues became part of the employment relationship. In contrast to the preceding era when local workers were deprived of labor organizations, the PNG government encouraged and even sponsored the formation of the first mining union in the Bougainville mine. Ahmed Ali and Alex Mamak claimed that the Bougainville Mine Workers Union (вмшч) resulted from a period of intensive industrial awareness created in the campaign by the government to get the largely nonunionized workforce into unions (I979). Bougainville Mine Workers became one of the largest unions in the country and was able to gain significant recognition from workers and the company. After seven years of registration this union staged one of Papua New Guinea's most militant strikes in response to management's patronizing attitudes, wage differentials, and more generally, the alien nature of the mine within agricultural communities on the island (Amarshi and others I979, I44; Quodling I99I, 39). Management paternalism as well as organizational problems haunted the union from its beginning and continued to do so (Ali and Mamak r979; Imbun r999a). But in the midI980s, before the closure of the mine, the Bougainville Mine Workers Union was one of the very few labor organizations in the country that possessed any real industrial muscle.

Similar labor issues at Ok Tedi mine in the I980s proved that Papua New Guinean mineworkers had become acutely conscious of their employment relationship. This was evidenced with the formation of two separate unions-the national white-collar workers had the Ok Tedi National Staff Association, while the blue-collar workers were represented by the militant Ok Tedi Mining Workers Union-comprising twothirds of the total workforce, which was I,800 strong in the r99os. Mike Hess and James Gissua attributed the major industrial dispute at Ok Tedi in 1988 to unresolved issues surrounding housing, training, and the failure of the company to reach national targets for employment of local peo- 
ple, as well as to changes in the shift system (1992). They claimed that the strike resulted from the operational problems of the union and an acute absence of systematically trained industrial relations officers who could have avoided the initial wildcat strikes by the preemptive handling of workers' grievances. In addition, the large-scale destruction of property by workers might not have happened if the disputants had easy and rapid access to industrial dispute settlement mechanisms, often a major hurdle in the operation of the industrial relations in Papua New Guinea (Hess and Gissua 1992, 49-50). However, the authors were unable to suggest how these mechanisms could be set up and maintained.

I found the same issues that triggered the I988 strike still surfaced in later meetings with the unions (Imbun I999b). But I also found that other issues such as "unequal" ethnic representation in the workforce and recruitment drives aimed at local landowning areas around the fringe of the mine affected the functioning of trade unions and the entire industrial relations framework at Ok Tedi (see also Jorgensen, this issue).

Subsequent mining developments in the country have generated a formidable pool of skilled local mining labor whose eagerness to become part of the emerging working class is unsurpassed in other developing countries. The awareness of their working conditions and associated workplace issues prompted workers to form unions in Misima and Porgera mines in the I990s. In its heyday of operation, the Misima Mine Workers Union had some 475 members out of a total workforce of 700 , and major negotiations took place between the union and management. However, the discussions were considered "cordial and friendly" and the entire industrial relations system was seen as stable, perhaps reflecting cultural norms of the peaceful island of Misima, from which almost all of the manual workforce originated (Imbun I999b, I6). In contrast, mining at Porgera has witnessed some militant industrial activities resembling those that occurred previously at Bougainville and Ok Tedi mines. The Porgera Mining and Allied Workers Union (PMAWU), representing some 80 percent of the nearly 2,000-strong workforce, has aggressively taken on the mine management on numerous occasions. Issues have ranged from wages and training to removal of expatriate line managers because of personality clashes. Workers at the Lihir mine, which began operations in the late I990s, have not had a union, as the management of the mine has been paternalistic and suppressive to the extent that workers found it extremely hard to organize unions for fear of instant dismissal (Interviews with several Lihir mine workers, Lihir Island, 8-I 2 Dec 2004). 


\section{Worker Attitudinal and Organizational Problems}

Despite their strategic location, mining unions' abilities to exist as efficient organizations and to independently pursue members' interests are fraught with attitudinal and organizational complications. Some of the problems stem from the transitory nature of the workforce. The necessary support had been slow in materializing because of the workers' inexperience in wage employment and because of the relative newness of the cash economy in general. Ali and Mamak observed that workers most willing to sign up for в MWU membership were those with some formal education and those who had been employed before (1979, 33). This has also been the case with the other mines. Ambivalence toward unionism was common among many local landowner employees who had little or no formal education (Imbun 2002). When some Porgera landowner employees were asked why they had not joined the union, they responded, "It [the union] is for the book people" and "It is against 'our' mine and boss all the time" (Interview with PMAWU general secretary, Io July 2002; see also Golub, this issue). They have openly pledged their loyalty to the policies and security of the mines. Their role has been one of providing a buffer between union and management and on some occasions they have broken strikes.

Similarly, organizational problems result from the composition of the unions' membership where the predominance of one large ethnic group of workers can create difficulties for the unions attempting to respond to the diverse demands of a heterogeneous workforce. Often industrial issues have become intertwined with the broad political and developmental aspirations of the mining provinces, complicating negotiations between unions and management. Further problems, inherent to each of the unions, are the appointment of union leaders and competition with other social organizations formed on the basis of ethnicity. A lack of financial and fulltime union officials also frustrates the unions' organizational abilities and thus affects their efficiency. The usual union membership fee of two kina per worker is meager, severely restricting the union's capacity to support a strike. Only the Misima Mine Workers Union and Porgera Mining and Allied Workers Union have a paid full-time worker in charge of running the union office. In each case the office is located in an abandoned government building away from the mine site. Generally, union leadership turnover is high and often some of the leaders do not possess the neces- 
sary experience, competence, and dedication to run such an organization. The two Ok Tedi unions and the Porgera union elect their executives at least annually, making it difficult to achieve continuity.

On the other hand, the desire by mining unions to achieve organizational efficiency has been further hindered by hostile foreign-dominated managements. The unions have blamed the managements for harboring narrow views, which see workers first and foremost as tribesmen rather than as members of an industrial working class. In fact, the expatriate mine managements view the unions as different in character from unions existing in their countries of origin such as Australia and Canada, merely because workers still have an overwhelming allegiance to the coexisting tribal social systems (Interview with PMAwU general secretary, Io July 2002). Such attitudes have continued to prevent management from acknowledging that unions and genuine industrial activities can coexist with tribal loyalties. Yet as the mines settle down, the former hostile approach of management is to some extent being replaced by attitudes of “controlled cooperation." But some of managements' antagonism toward unions cannot be hidden. On one project site I visited on 26 May I996, trade unionists were often accompanied by company-employed dog handlers and their Alsatians when meeting with management.

Generally, mining unions are further constrained by the largely reactive role of the PNG government in industrial relations. The Department of Labor and Employment responds to industrial disputes in the mines on an ad hoc basis, largely through the conciliation process, and, in some extreme cases, the establishment of a commission of inquiry. With some parts of the industrial relations tribunal system defunct, the government's lack of financial resources, and the absence of sufficient specially trained industrial relations officers, the problems of unionism's effectiveness in the mines have compounded.

\section{LABOR ISSUES}

In the mining projects, workers' issues regarding employment conditions are ever present. Labor issues are not unique to PNG mining, as mines elsewhere experience the rough and tough behavior of miners. But in the Papua New Guinea context, industrial conflict has arisen from both structural and interpersonal problems. Most of the issues a mining union takes up arise out of management's inability to deal with workers' long-standing grievances. The issues are largely the same in every mine, ranging from wages, accommodation, training, localization, and safety, to recognition 
of trade-union activities. Papua New Guinean workers are aware that they are paid a fraction of what expatriates earn for the same job, and this is a perennial source of grievance. The disparity is at least relieved by the fact that within the country miners' wages are relatively high, up to three times higher than for workers in other sectors of the economy, but with the inflated prices of goods and services in the rural domain, the wage issue is pressing. The accommodation issue centers on management's favored single-person, transitory provisions, which parallel the "fly-in, fly-out" living arrangements of management. However, any union policy would favor the creation of a proper mining town with adequately serviced family houses and other necessary amenities. Further, the expatriate management is constantly blamed for not doing enough to address the localization and training issues that inhibit the promotion of Papua New Guineans to line management positions. Occasionally, safety becomes a contentious problem, though not as urgent as the other three issues mentioned (Imbun 2002).

Interpersonal conflicts at the mine sites stem from traditional social values, which privilege ideals that are in direct contrast to modern management practices. Tribal miners perceive work as belonging to individuals, not to institutions. Such a perspective obliges managers to earn respect rather than require it as a right. This orientation to work relations has caused interpersonal conflicts between expatriate managers and supervisors who are heads of the various departments. Generally, managers adopt a formal and authoritative style, which leaves little avenue for interactive communication with the workers. The constant supervision of the laborious and monotonous aspects of some work such as truck hauling and heavy equipment operation has led workers to frequently complain about lack of flexible work arrangements (Interview with PMAWU shop steward, I2 July 2002). Because of the rigid work schedule it is not surprising to see a high rate of unauthorized absenteeism in these jobs.

There have been numerous allegations of confrontation between workers and expatriate supervisors in the mines. Some of the problems occur as a result of communication differences. Only a handful of workers can speak English, which is the lingua franca of the mines. Some Porgeran workers who were members of PMAwU believed that their supervisors considered them backward and unable to think for themselves. In turn, there are cases of indigenous workers verbally and physically assaulting expatriate management. This was a big problem at the Bougainville mine; now violence and threats have also begun to be a problem at the Porgera site, where six workers were terminated for "manhandling" their super- 
visors at the workplace in I99I (Interview with PMAWU organizer, I 2 July 2002). Direct personal contact between expatriates and Papua New Guineans is largely superficial, with any familiarity seldom extending outside the workplace. The supervisor-worker clash is compounded by the underlying hostility that stems from the dual wage system, which favors the expatriates, and the management structure, which increasingly favors expatriates in the allocation of housing and core jobs in the mines.

\section{A Genuine Industrial Workforce?}

Unlike in developed countries where a person's "orientation to work" is influenced by their family, community, and class situations (Goldthorpe I980), Papua New Guinean miners generally have no previous wage employment experiences to shape their perceptions and attitudes. Ron K Brown and Paul Brannen (1970, I) and Well Daniel (I970, I99) mentioned that western miners' attitudes and expectations of work could effectively be understood in terms of their work, community, and craft traditions. Because the opening of the mines and the general introduction of capitalism into the country are both so recent, it is not surprising that sometimes tribal miners' attitudes toward work and reward seem odd and unpredictable. Often Papua New Guinean miners' attitudes and behavior at work are determined by external factors.

During my extensive fieldwork in Porgera mine from the mid-I990s to 2000 , I observed several strategies of involvement in the workforce. Porgeran mineworkers have developed their skills not only in employment but also in village activities and businesses. Attitudes toward employment varied among the many Porgeran mineworkers I interviewed. Several interviewees considered wage employment to be the easiest (though not necessarily the most desirable) way of generating cash income. However they were adamant that they wanted to be wage earners for the rest of their lives. They stressed the importance of a continual supply of money now that Porgera has opened up to the rest of the country and now that more economic activities are taking place in the area. In the interviews they often repeated their desires to build permanent houses, to raise cash crops and livestock, to invest in tribal business associations, to possess a wide range of consumer goods and appliances, and to have their children educated.

The views expressed by the Porgeran mineworkers can be broadly grouped under three common approaches to general wage employmentthe first three of four stages identified by Clark Kerr, John T Dunlop, 
Frederick H Harbison, and Charles A Myers in their study of behavioral change that indicate the level of commitment by workers to industrial employment (1960). They are, first, the "tribal strategy"; second, the "entrepreneur strategy"; and third, the "worker strategy." (In an earlier paper, I looked at these strategies from an economic perspective; see Imbun 2000, I37.)

\section{Tribal Strategy}

Many of the Porgeran workers who adopted the tribal strategy were unskilled or semiskilled, and expressed the lowest degree of commitment to mine work. They resemble what Kerr and his coauthors called the "uncommitted worker," who has no intention of entering industrial employment on a continuing basis. Therefore, the uncommitted Porgeran workers considered their involvement in mine work to be peripheral, while attending to tribal obligations was of prime importance. They mentioned their desire to accumulate enough money through their wages to attend to tribal activities such as hosting occasional pig exchange ceremonies, settling differences with enemy tribes, and paying bride prices for more wives to consolidate their "bigman" status in their villages. They regarded herding more livestock and venturing into some kind of entrepreneurial activity to provide a steady income in their villages as viable alternatives to mine work. They mentioned that the skills (carpentry, driving, accounting, and operating heavy equipment) they acquired while working for the mine would enable them to start their own economic endeavors in the village. Most saw their mine work as a means of providing more satisfactory and wider involvement in the village. However, as one man remarked, "With only my driving license I can not go far when Porgera closes, so working on the land helps me to establish my future at home" (Interview with Porgeran miner, 22 Dec 200I). Those in the uncommitted group were also somewhat like the "target workers" in the former apartheid South African gold mines, whose embrace of employment was temporary and undertaken for an immediate purpose (Kerr and others I960, I7I).

\section{ENTREPRENEUR STRATEgy}

The second approach, the entrepreneur strategy, is characterized by participation in wage employment at the same time as other economic pursuits, especially business enterprises. Only a small proportion of inter- 
viewees chose to spread their time, labor, and capital assets over a range of town- and village-based activities. According to Kerr and his coauthors, such workers are semi-committed to industrial work because they are at the margin of two ways of life; they may work regularly but maintain their connection with the land, the tribe, or the village (I960, I7I). These Porgeran entrepreneurs were from villages immediately surrounding the mine and Porgera town who supplemented their wage income with money derived from participation in other economic ventures. These ventures ranged from running small retail shops, workshops, and petrol stations, to operating bus lines and raising chickens. However, the most profitable enterprises were those contracted to the mine, including construction, transportation, laundering, catering, cleaning, and security. Mostly, the workers' kinsmen ran the businesses and the entrepreneurs themselves only participated after mine work and on weekends. The entrepreneurs were a privileged few who had a sound financial base not only because of the wages they earned from the mine but also from royalties and other compensation benefits if their villages were close to the mine. They demonstrated their wealth and status, for example, by driving new fourwheel-drive vehicles, living in high-rise corrugated-iron-roofed houses, and marrying more than one wife.

Porgerans who adopted the entrepreneur strategy were found in all levels, from the unskilled to those employed in senior positions. They were likely to be given preferential treatment from Porgera Joint Venture (PJV), receiving new spin-off contracts and management assistance. Because of general minimal understanding about the basics of doing business, most of their business enterprises have failed. These failures have been blamed mainly on lavish spending by the owners. During the period of my interviews, some of the bigger Porgeran businesses were saved from bankruptcy through the intervention of PJV management personnel.

\section{Worker Strategy}

The third approach, unlike the first two strategies, involved some generally better-educated Porgeran workers with a stronger commitment to their jobs. Although very small in number, they included the few educated Porgerans who saw wage employment as the sole source of cash income. Although they had a general commitment to work, they did not strictly resemble Kerr and his coauthors' "fully committed workers," who became permanent members of an urban, industrial, or urban workforce (I960, I7I). Instead, these Porgeran workers have not severed their connections 
with their villages, despite having very little intention of investing their earnings in village economic activities. Those who exhibited this "worker strategy" also wanted to stay in the jobs as long as the mine lasted. This group differed from the other Porgeran workers in that they wanted job stability and were prepared to make adjustments to accommodate all the institutional aspects of urban living and industrial employment; this is very much one of the features of a committed industrial workforce. They also desired mobility in their jobs so that they could go and work in other Papua New Guinea mines-despite the Porgera mine work arrangements where all Porgerans commuted to the mine from their villages. The desire to belong to the country's already emerging working class was evident when they talked of sending their children to the best schools in the country so that they could end up with well-paying jobs. Some mentioned that they were loyal PMAWU members and expressed much concern about the company's wage rates, accommodation policies, localization policies, management-worker relations, and social problems. However, these views were similar to those who were isolated from their villages and found themselves in an urban milieu. Two recent college graduates in accounting, for example, mentioned their concern about the high cost of living associated with town residence, but they also lamented the fact that in the villages they were obliged to support their immediate relatives (Interview with Porgeran miners, 22 Dec 200I).

The fourth stage identified by Kerr and his coauthors, the "specifically committed worker" (I960, I72), who meets all the requirements of an industrial workforce on the continuum of behavior change, has yet to develop among Porgeran and other Papua New Guinean workers. This is because attachments to the industrial way of life, to a particular employer and often to a particular occupation have not yet developed in the country. However, this stage may emerge in the future when the country achieves a higher stage of industrial employment.

\section{Where to Now?}

This paper has attempted to illustrate the challenging circumstances Papua New Guineans have had to endure and emerge from, as they have been absorbed in mining employment. Their involvement in the industry has varied from furnishing casual labor in the late 1800 s and serving under the indentured system in the I920s to becoming independent wage earners in the modern period. Different sets of social, legal, economic, and political circumstances have regulated their participation in each phase of 
their engagement over the decades. They have gone through the hardship of liberating themselves from the tentacles of often aggressive and paternalistic miners and indenture laws in the past decades, but in the current milieu a different set of challenges confronts them.

The gradual imposition of a modern economy on a centuries-old social and cultural landscape, which had an earlier superficial colonial presence, is partially responsible for the local miners' varying perceptions of paid work. Arguably there were no distinctively compatible capitalistic characteristics in traditional Papua New Guinean society to give local laborers a head start in embracing the modern concept of work. Therefore, various differences exist between the Papua New Guinean miners and their counterparts in advanced countries.

Local variations and distinctive local features influence workers in different locales. For example, the Papua New Guinean miner does not closely resemble the old-time British collier, the underground coal miner who is a staunch trade unionist and very conscious of his "class position" in a traditional and conservative single-industry community. In the case of the average Porgeran miner, he is first a tribesman and then a semiskilled individual worker, and this allows him to freely rotate between paid work and his other essential source of survival and community solidarity, namely subsistence farming. Belonging to a trade union is not very crucial because he is constrained by more than economic necessity in seeking and maintaining his work. He has not even become as urbanized as the colliers of England and Australia who live in mining towns and villages.

Another crucial feature of the Papua New Guinean experience of mining that differentiates it from the Western popular stereotype has been the role of indentured mine labor. Like bonded labor in some earlier Asian mines and convict labor in China, Japan, and later in Australia, indentured Papua New Guinean mine labor in the r930s and r940s demonstrated the complex social relations and endured conditions of exploitation in a quite different social context from the stereotypical Western male collier. The Papua New Guinean mineworkers' labor was indentured and compulsory and their wages were paid in kind rather than cash to comply with the labor policies of a paternalistic colonial administration. Much of their dissatisfaction over working conditions was reflected in various forms of covert conflict.

Additionally, unlike the committed Western miner whose orientation to work is a result of experience, tradition, and community situation, many Papua New Guinean tribal workers with their very basic understanding of 
formal industrial and employment relations still perceive work as belonging to individuals and not institutions. In order to motivate them to do a required amount of work, the manager responsible must be capable of communicating with them in a fairly intensive way. Although such skills are applied by managers in workplaces elsewhere, what is particularly demanding about PNG workplaces is the workers' overwhelming expectation that their manager to be like their typically traditional but benevolent village bigman or chief. Besides technical and coordinating skills, a manager at this stage of development is required to emulate the kinder and familiar qualities of a bigman (such as consideration, kindness, and understanding) in order to have a sound workplace that is conducive to increasing productivity. If a Western manager pursues an insensitive approach to local circumstances, he can expect a decline in productivity from tribal miners.

Another notable difference can be seen in the ways Papua New Guinean tribesmen have assimilated the modern concept of mine work. For most, jobs have been seen as stepping-stones to advancement to other activities outside mining. As mentioned earlier, the illiterate and unskilled Porgeran workers have the lowest degree of commitment to mine work. They want to accumulate enough money to attend to various tribal activities. Some of them also have entrepreneurial aspirations, which will lead them to get involved with businesses while employed in the mine. Only a privileged few educated persons resemble the Western miner who sees wage employment as the sole source of a cash income.

However, at the time of writing, several characteristics seem to point to the shaping and consolidation of a significant mining working class ready to establish its mark on the country's economic and social development landscape. Although it may first seem that Papua New Guinean miners are at an early stage in the culture of industrialization, a growing number of miners now have exclusive commitment to wage labor and the industrial way of life. The expansion of the country's mineral economy is also contributing to the creation of a versatile and mobile skilled workforce. Despite the closure of Misima mine, there is cause to believe the mining labor market will expand in proportion to the development of Kainantu gold mine, Ramu, and two more new mines to be commenced in 2006, and another three or four planned for the subsequent years. Some of the former Misiman miners are expected to be absorbed into the Kainantu mine workforce and others to be recruited for the subsequent new mines. 
There is already a noticeable increase in labor mobility taking place between the mines. Although it is a natural development of any industry for workers to become more mobile, it is interesting to see first-generation wage earners moving from one mine to the next in search of better terms and conditions. Many Porgeran workers, in particular, have gone to Lihir and Tolokuma mines to seek employment; Lihirians, Tolokumans, and local Ningirum and Telefomin workers from Ok Tedi have done the same. The trend is set to continue, as there is now emerging a sizable mining labor market. In fact, overseas job attachments and permanent moves have occurred recently with the placements of four Porgera mine employees taking up jobs in a mine in East Africa run by Placer Dome (National 2005). Several local miners have sought and gained jobs in Australian mines in 2004. If these developments are any indication, one thing is certain: the standard outsider's caricature of the Papua New Guinean worker as an uncommitted worker will gradually become a thing of the past. As more mining workers become compelled to work for an industry in search of an alternative livelihood they are drawn into, consciously or unconsciously, they are becoming a formidable working class.

\section{References}

Ali, Ahmed, and Alex Mamak

I979 Race, Class and Rebellion in the South Pacific. Sydney: George Allen and Unwin.

Amarshi, Ahmed, Kenneth Good, and Rex Mortimer

1979 Development and Dependency: The Political Economy of Papua New Guinea. London: Oxford University Press.

Brown, Ron K, and Paul Brannen

I970 Social Relations and Social Perspectives amongst Shipbuilding Workers: A Preliminary Statement. Sociology 4:7 I-84.

Connell, John, and Richard Howitt, editors

I99I Mining and Indigenous Peoples in Australasia. Sydney: Sydney University Press.

Daniel, Well

I970 Industrial Behaviour and Orientation to Work-A Critique. Journal of Management Studies 7:199-208.

Filer, Colin

I990 The Bougainville Rebellion, the Mining Industry and the Process of Social Disintegration in Papua New Guinea. Canberra Anthropology I $3:$ I -39 . 
I998 The Melanesian Way of Menacing the Mining Industry. In Modern Papua New Guinea, edited by Laura Zimmer-Tamakoshi, I47-I77. Kirksville, mo: Thomas Jefferson University Press.

Fitzpatrick, Peter

I978 "Really Rather Like Slavery": Law and Labour in the Colonial Economy of Papua New Guinea. In Essays in the Political Economy of Australian Capitalism, edited by Edward L Wheelwright and Ken Buckley, Io8-i 8 . Sydney: ANz Press.

Gammage, Bill

I975 Rabaul Strike, I929. Journal of Pacific History 10:3-29.

I998 The Sky Travellers: Journey in New Guinea, 1938-1939. Melbourne: The Miegunyah and Melbourne University Press.

Gibbney, Herbert James

I972 The New Guinea Gold Rush of i 878. Journal of the Royal Australian Historical Society 58:284-296.

Goldthorpe, John H

I980 Social Mobility and Class Structure in Modern Britain. New York: Oxford University Press.

Hess, Mike, and James Gissua

I992 Unions and Industrial Relations in Papua New Guinea. New Zealand Journal of Industrial Relations I7:39-55.

Imbun, Benedict Y

I999a Industrial and Employment Relations in the Papua New Guinea Mining Industry. Waigani: University of Papua New Guinea.

I999b The Dynamics of Industrial Relations in the Papua New Guinea Mining Industry: Implications for Trade Union Policies. National Research Institute Discussion Paper 90. Boroko, PNG: National Research Institute.

2000 Mining Workers or "Opportunist” Tribesmen? A Tribal Workforce in a Papua New Guinea Mine. Oceania 7I:I29-I49.

2002 Trade Unions or Tribal Organisations? The Genesis of Porgera Mining and Allied Workers Union in Papua New Guinea. Labour and Management in Development Journal 3:I-I7.

Kerr, Clark, John T Dunlop, Frederick H Harbison, and Charles A Myers

I960 Industrialism and Industrial Man: The Problems of Labour and Management in Economic Growth. London: Heinemann.

National (Port Moresby)

2005 Porgeran miners going offshore. 24 January.

Nelson, Hank

1976 Black, White and Gold: Gold Mining in Papua New Guinea I8781930. Canberra: Australian National University Press. 
I992 Gully-Rakers, Mining Companies and Parallels of War. In Resources, Development and Politics in the Pacific Islands, edited by Stephen Henningham and Ron May, I I-29. Bathurst: Crawford House Press.

Newbury, Colin

I975 Colour Bar and Labour Conflict on the New Guinea Goldfields Parr, Egan A I935-4I. Australian Journal of Politics and History 2I:25-38.

I974 Edie Creek I926-I927: The Indian Summer of Red-Shirt Capitalism. BA Honours thesis, Department of History, University of Papua New Guinea.

Quodling, Paul

I99I Bougainville, The Mine and The People. Sydney: The Centre for Independent Studies.

Rumsey, Allan, and James Weiner, editors

200I Mining and Indigenous Lifeworlds in Australia and Papua New Guinea. Adelaide: Crawford House.

Sinclair, James

I978 Wings of Gold: How the Aeroplane Developed New Guinea. Sydney: Pacific Publications.

Waiko, John

I993 A Short History of Papua New Guinea. Melbourne: Oxford University Press.

Ward, Gerard

I990 Contract Labor Recruitment from the Highlands of Papua New West, Fred J Guinea, I950-I974. International Migration Review 24:273-296.

I95 8 Indigenous Labour in Papua and New Guinea. International Labour Review 77:9-I2.

\section{Abstract}

This paper examines Papua New Guinean participation in mining from the perspective of furnishing labor. It throws light not just on current employment arrangements but also on the historical emergence of the local miner and wider canvas of age-old attitudes and traditions influencing workers' perspectives on work. Analysis of a variety of data collected through interviews, document analysis, and direct observations of a number of events in Porgera and other mines indicate that Papua New Guinean mine workers are in a transitional phase of becoming full-fledged workers. Many of the current challenges stem from the recent introduction of capitalism into the previously predominantly subsistence 
sector. However, there is sufficient evidence to suggest that local mine workers are becoming more attached to paid work and this attitude is embraced by an increasing number of educated and skilled workers. This trend is set to continue as more mines become operational and as the country in general develops economically.

KEYwORDs: Papua New Guinea, labor, mining, mine workers, industrial relations 